UDK: 37.011.3:165.195

Izvorni naučni rad

Primljeno: 1. 9. 2019.

Prihvaćeno za štampu: 13. 1. 2020.

dr. sci. Fehim Rošić, redovni profesor

Univerzitet u Bihaću

Islamski pedagoški fakultet

E-mail:fehim.rosi@@gmail.com

\title{
EMOCIONALNA KOMPETENTNOST U NASTAVNIČKOJ PROFESIJI
}

\section{Sažetak}

Problem ovog istraživanja obuhvata emocionalnu kompetentnost nastavnika, a cilj istraživanja je ispitivanje značaja i veličine uticaja spola, vrste nastave, starosne dobi i dužine radnog staža nastavnika na nivo njihove emocionalne kompetentnosti. Istraživanje je obavljeno Upitnikom UEK-45 na uzorku od 225 nastavnika osnovne i srednje škole s područja Unsko-sanskog kantona, a po nacrtu spada u komparativna istraživanja, retrospektivno-prospektivnog tipa. Rezultati istraživanja su pokazali postojanje razlika $u$ aritmetičkim sredinama ukupnog rezultata i rezultata na subskalama upitnika UEK-45s obzirom na kriterijske varijable spola, vrste nastave, starosne dobi $i$ dužine radnog staža nastavnika. Testiranjem značajnosti ovih razlika t-testom $i$ Analizom varijanse (ANOVA) potvrdena je značajnost razlika: s obzirom na vrstu nastave na subskali uočavanja $i$ razumijevanja emocija (URE), s obzirom na starosnu dob na subskali regulacije $i$ upravljanja emocijama (RUE) mecu ispitanicima starosne dobi 25-34 godine i onih sa 45 i više godina, te na subskali izražavanja i imenovanja emocija (IIE) s obzirom na razliku starosne dobi $i$ dužine radnog staža između nastavnika s ovom razlikom u intervalu 25-34 godine i onih sovom razlikom od 45 i više godina.

Ključne riječi: emocionalna kompetentnost, uočavanje $i$ razumijevanje emocija, imenovanje $i$ izražavanje emocija, regulacija $i$ upravljanje emocijamama, empatija. 


\section{UVOD}

U novijem pristupu ljudskim resursima, potencijalima i proučavanju efikasnosti ljudske djelatnosti uveden je konstrukt ili termin kompetencija ili kompetentnosti koji u najširem smislu obuhvata potrebna znanja i vještine za obavljanje neke djelatnosti. Suzić (2005) navodi dvadeset i osam kompetencija koje su svrstane u četiri osnovne grupe: kognitivne, socijalne, emocionalne i radno-akcione kompetencije.

Kognitivne (racionalne ili intelektualne) kompetencije odnose se uglavnom na prosuđivanje, registriranje, analizu i evaluaciju informacija koje osoba ima na raspolaganju, koristeći se mentalnim procesima i operacijama. Ova grupa obuhvata sedam ključnih kompetencija: a) izdvajanje bitnog od nebitnog, b) postavljanje pitanja o gradivu i o vlastitoj kogniciji, c) razumijevanje materije i problema, d) odabir informacija koje je nužno upamtiti, e) rukovanje informacijama, brzo pronalaženje, korištenje i pohranjivanje informacija, f) produkcija novih ideja, rješenja i produkata, g) vrednovanje efikasnosti učenja i rada.

Socijalne kompetencije se odnose na socijalno funkcioniranje individue, a obuhvataju, također, sedam osnovnih kompetencija: a) razumijevanje drugih individua $\mathrm{i}$ grupa, tumačenje grupnih odnosa $\mathrm{i}$ njihove snage, b) usaglašenost s ciljevima grupe ili organizacije, c) stvaranje veza, sposobnost uvjeravanja, organizacione i timske sposobnosti, d) nenasilno komuniciranje, sposobnost slanja i primanja poruka, e) podrška drugima, senzibilitet za potrebe drugih, f) tolerancija i uvažavanje različitosti, g) osjećanje pozitivne pripadnosti naciji i civilizaciji.

Radno-akcione kompetencije podrazumijevaju individualne sposobnosti za izvršenje nekog zadatka ili aktivnosti, a obuhvataju: a) poznavanje struke ili profesionalnost, b) opću, informatičku i komunikacijsku pismenost, te poznavanje stranog jezika, c) savjesnost i preuzimanje odgovornosti za lična ostvarenja, d) ustrajnost u ciljevima uprkos preprekama ili neuspjesima, e) motiv postignuća, težnja za poboljšanjem ili ostvarenjem najviših kvaliteta, f) inicijativa, spremnost da se iskoriste ukazane mogućnosti, g) optimizam, unutrašnja motivisanost, volja za rad. 
Emocionalne kompetencije se odnose na sposobnost individue da razumije vlastite i emocije drugih, da upravlja svojim emocijama, da ih usavršava i koristi u socijalnim i životnim situacijama, a obuhvataju:

a) Emocionalnu svijest, prepoznavanje svojih i tudih emocija. Ova kompetencija ima značajnu kognitivnu dimenziju jer se radi o kognitivnim procesima obrade pobuda kojima postajemo svjesni svog emocionalnog stanja i tek nakon tog svjesnog prepoznavanja možemo upravljati svojim emocijama. Goleman (1998. prema Suzić, 2005) iznosi da emocionalna svijest, odnosno, prepoznavanje svojih i tuđih emocija ima četiri komponente:

- znamo koje emocije imamo i zašto,

- shvatamo veze između mišljenja i emocija,

- prepoznajemo kako osjećanja utiču na rad i učinak i

- imamo emocije vodilje koje su bazirane na svijesti o vrijednostima i ciljevima.

b) Jasan osjećaj vlastitih moći $i$ limita, samopouzdanje. Samopouzdanje se zasniva na vlastitoj percepciji i osjećaju sopstvenih moći i potencijala. Osoba koja nema samopouzdanje kao kompetenciju pokazuje slijepe i/ili nerealne ambicije, preokupiranost javnim pokazivanjem, pretjerano snažnu potrebu za priznanjima, pritisak na druge i potrebu da izgleda savršeno. (Kaplan, 1991).

c) Samokontrolu ometajućih emocija $i$ impulsa. Kontrola emocija se može vršiti uglavnom na dva načina: a) kontrolom izražavanja emocija i b) kontrolom doživljavanja emocija. Ometajuće emocije mogu blokirati korisne i potrebne akcije i misli. Samokontrola ovakvih emocija ne znači njihovo potiskivanje: samokontrola se odnosi na svijest o emocijama, njhovoj štetnosti ili korisnosti, a potiskivanje predstavlja svjesnu ili nesvjesnu kognitivnu zabranu ili barijeru za ove emocije (Milivojević, 2000).

d) Empatiju i altruizam. Upotreba termina empatija datira iz 1897. godine i vezuje se za ime njemačkog psihologa Theodora Lippsa, a kasnije je taj termin određen kao uživljavanje, akt projiciranja samog sebe u nečiji položaj, kao oblik identificiranja s nekim. Savremeno objašnjenje i definiranje empatije izbacuje ovu dimenziju identificiranja i u prvi plan stavlja rezonanciju doživljavanja u nama 
samima emocionalnog tona koji proživljava druga osoba, a ne puko identificiranje (Bratanić, 1993). U razmatranju emocionalne kompetentnosti uz empatiju se vezuje i pojam altruizma (Suzić, 2005), jer ako bi se ova dimenzija emocionalne kompetentnosti svela samo na empatiju bez altruizma, bile bi moguće i negativne emocije, jer našim uživljavanjem u emocije drugih možemo doživjeti ljubomoru, zavist ili prezir, pa stoga empatijski kapacitet, koji obuhvata obje ove dimenzije, predstavlja neophodnu komponentu emocionalne kompetentnosti $\mathrm{u}$ pomažućim profesijama.

e)Istinoljubivost, izgradnju standarda časti i integriteta. Da bi čovjek djelovao i mislio u skladu s etičkim standardima, mora izgraditi vlastite etičke standarde, a to ne može bez učešća emocija, bez pozitivne emocionalne opredijeljenosti prema sebi i prema cjelokupnom okruženju. Individua živi u stalnoj interakciji s okolinom i preispituje svoje stavove, norme i uvjerenja kognitivnim procesima, ali i uz potpunu proživljenost $\mathrm{i}$ ispunjenost emocijama: ne možemo se suprotstaviti neetičkim aktima drugih bez vlastitog emocionalnog proživljavanja, niti možemo prilikom priznavanja vlastite greške izbjeći emocionanu komponentu. (Goleman, 1998) Istinoljubivost podrazumijeva: djelovati etički i ne plašiti se grdnje zbog toga, graditi povjerenje autentično i putem veza, priznati vlastite greške i suprotstaviti se neetičkim aktima ostalih, dok savjesnost obuhvata: ispunjenje obaveza i obećanja, postojana odgovornost u izvršavanju svojih ciljeva, te sistematičnost $\mathrm{i}$ organiziranost u svom poslu.

f) Fleksibilnost u prihvatanju promjena, adaptibilnost. Adaptibilnost podrazumijeva emocionalnu stabilnost, ali i kreativnost i otvorenost za inovacije. Kompetencija adaptibilnosti i fleksibilnosti u prihvatanju promjena podrazumijeva otvorenost za nove ideje i pristupe te fleksibilnost u reagiranju na promjene. Ona obuhvata: snalaženje u mnogostrukim zahtjevima, izvođenje prioriteta i efikasnih promjena, prilagođavanje vlastitih odgovora različitim okolnostima, te fleksibilnost načina sagledavanja događaja.

g) Otvorenost za nove ideje, pristupe $i$ informacije. Ova emocionalna kompetencija se prvenstveno zasniva na kreativnosti kao kognitivnom manifestnom izrazu, a emocionalna komponenta, kod osobe koja je inovativna, obuhvata zadovoljstvo, oduševljenje, ushićenje i zanos. Kvalitet i zadovoljstvo životom značajno zavisi od toga koliko volimo 
ono što moramo da radimo, pa je ova emocionalna kompetencija posebno značajna u svakoj profesiji.

Davies i Bryer (2004) su utvrdili da emocionalno kompetentni učitelji ostvaruju kvalitetniju nastavu, potiču razvijanje emocionalne kompetencije učenika, razvoj kvalitetnijeg prepoznavanja i upravljanja emocijama kod njih, te kontroliranje vlastitih emocionalnih reakcija, rast empatijskog kapaciteta i razvoj prosocijalnog ponašanja.

Goleman (2009) nalazi da emocionalna inteligencija predstavlja potencijal za učenje praktičnih vještina koje se temelje na samosvijesti, motiviranosti samoregulaciji, empatiji i kvalitetnom stvaranju mađuljudskih odnosa. Ovo saznanje ima poseban značaj, s obzirom da je odgojno-obrazovni proces poseban i veoma kompleksan međuljudski odnos.

Rezultati istraživanja (Reić - Ercegovac, I., Koludrović, M., Jukić, T., 2009) su pokazali značaj emocionalne kompetentnosti na različite aspekte stresa $u$ nastavničkom zanimanju. Utvrđena je statistički značajna povezanost između samoprocjene emocionalne kompetentnosti nastavnika i većine vidova nastavničkog stresa, pri čemu nastavnici koji se doživljavaju emocionalno kompetentnijima, općenito doživljavaju manji stres u svom poslu. Pokazalo se da emocionalna kompetentnost općenito, a posebno neki aspekti emocionalne samoregulacije, značajno doprinose zadovoljstvu poslom i pozitivnijim stavovima prema učenicima.

Dostignuti nivo saznanja savremene pedagogije ukazuje na veoma važan značaj emocionalne kompetentnosti nastavnika u odgojnoobrazovnom procesu, ali istovremeno otvara i pitanje sticanja ovog svojstva i vještina tokom odgoja i cjelokupnog obrazovanja, a posebno profesionalnog u ovoj oblasti. Tradicionalna podjela odgoja na pet osnovnih područja: intelektualni, tjelesno-zdravstveni, moralni, estetski i radno-tehnički odgoj je prevaziđena i svakako je nužno uključiti i posebno područje sistematskog emocionalnog odgoja. 


\section{METODOLOŠKI OKVIR}

\section{Predmet, problem i cilj istraživanja}

Predmet ovog istraživanja je emocionalna kompetentnost nastavnika osnovne i srednje škole, a problem se odnosi na ispitivanje značaja i veličine uticaja statusnih nezavisnih obilježja ili varijabli na ukupni nivo emocionalne kompetentnosti i na posebne dimenzije kao komponente ove kompetentnosti.

Cilj istraživanja je da se utvrdi, analizira i interpretira značaj i veličina uticaja spola, starosne dobi, dužine radnog staža i vrste posla nastavnika na ukupan nivo njihove emocionalne kompetentnosti i na svaku od tri dimenzije ili komponente ove kompetentnosti.

\section{Varijable $\boldsymbol{i}$ instrumenti}

Nezavisne varijable u ovom istraživanju su spol, starosna dob, dužina radnog staža i vrsta posla nastavnika osnovne i srednje škole, a zavisna varijabla je emocionalna kompetentnost ovih ispitanika.

Podaci za nezavisne varijable su prikupljeni anamnestičkim upitnikom, a podaci za emocionalnu kompetentnost su prikupljeni Upitnikom emocionalne kompetentnosti (Takšić, 2002)

Upitnik emocionalne kompetentnosti predstavlja petostepenu skalu samoprocjene Likertovog tipa od 45 čestica. Upitnik je u psihometrijskoj analizi autora, nakon inicijalne primjene, pokazao trofaktorsku strukturu, ali autor izvornika smatra opravdanim i formiranje jednog rezultata koji se odnosi na samoprocjenu opće i ukupne emocionalne kompetentnosti.

U inicijalnoj primjeni autora pouzdanost Upitnika se pokazala zadovoljavajućom (Crombach $\alpha=0,92$ ), a prosječna korelacija među česticama iznosila je 0,23. Upitnik mjeri tri aspekta emocionalne kompetentnosti: a) sposobnost uočavanja i razumijevanja emocija (URE; 15 čestica), b) sposobnost izražavanja i imenovanja emocija (IIE ; 14 čestica) i c) sposobnost regulacije i upravljanja emocijama (RUE; 16 čestica). Sve subskale su u inicijalnoj primjeni autora pokazale zadovoljavajuće pouzdanosti na različitim uzorcima, od $\alpha=0,71$ do $\alpha$ $=0,90$. Upitnik emocionalne kompetentnosti (UEK - 45) je preveden $\mathrm{i}$ 
validiran u nekoliko zemalja: Slovenija (Avsec, 2005. godine), Španjolska (Extremera i Fernández-Berrocal, 2005.godine), Portugal (Faria i Lima Santos, 2005. godine), Švedska (Molander, Holmström i Jansson, 2005. godine), Finska (Räty, 2005.) i Japan (Toyota, 2005.). Upitnik je pokazao zadovoljavajuće metrijske karakteristike u svim ovim zemljama. (Takšić, 2002)

\section{Hipoteze}

U skladu s problemom i ciljem istraživanja postavljene su polazne radne hipoteze:

H-1: Postoje statistički značajne razlike u prosječnom nivou sposobnosti uočavanja $i$ razumijevanja emocija (URE) među ispitanicima s obzirom na spol, starosnu dob, dužinu radnog staža $i$ vrstu posla koji obavljaju.

H-2: Postoje statistički značajne razlike u prosječnom nivou sposobnosti izražavanja i imenovanja emocija (IIE) među ispitanicima s obzirom na spol, starosnu dob, dužinu radnog staža $i$ vrstu posla koji obavljaju.

H-3: Postoje statistički značajne razlike u prosječnom nivou regulacije i upravljanja emocijama (RUE) među ispitanicima s obzirom na spol, starosnu dob, dužinu radnog staža i vrstu posla koji obavljaju.

H-4: Postoje statistički značajne razlike u prosječnom nivou ukupne emocionalne kompetentnosti (UEK) među ispitanicima s obzirom na spol, starosnu dob, dužinu radnog staža i vrstu posla koji obavljaju.

\section{Uzorak}

Uzorak u ovom istraživanju obuhvatio je 223 nastavnika osnovne i srednje škole s prostora Unsko-sanskog kantona. Po tipu je slučajnog izbora, s ravnomjernim procentnim kvotama po izdvojenim obilježjima u odnosu na populaciju. 
Tabela 1: Struktura uzorka prema statusnim obilježjima ispitanika

\begin{tabular}{|c|c|c|c|c|c|}
\hline \multirow{2}{*}{\multicolumn{2}{|c|}{ Obilježja }} & \multicolumn{2}{|c|}{ Spol } & \multicolumn{2}{|c|}{ Vrsta nastave } \\
\hline & & $\bar{M}$ & $\overline{Z Z}$ & Razr. & Predm. \\
\hline \multirow{3}{*}{ 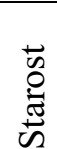 } & 25-34 god. & 5 & 37 & 32 & 10 \\
\hline & 35-44 god. & 25 & 77 & 80 & 22 \\
\hline & 45 i više god. & 13 & 66 & 65 & 14 \\
\hline \multicolumn{2}{|c|}{ Ukupno } & 43 & 180 & 177 & 46 \\
\hline \multirow{4}{*}{ 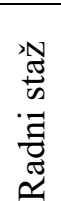 } & do 10 god. & 9 & 40 & 40 & 9 \\
\hline & $10-19$ god. & 16 & 71 & 57 & 30 \\
\hline & 20-29 god. & 16 & 67 & 78 & 5 \\
\hline & 30 i više god & 2 & 2 & 2 & 2 \\
\hline \multicolumn{2}{|c|}{ Ukupno } & 43 & 180 & 177 & 46 \\
\hline
\end{tabular}

U uzorku je veća zastupljenost ženskog spola, što po ovom obilježju odgovara odnosu i u populaciji.

\section{REZULTATI I DISKUSIJA}

\section{Karakteristike distribucije frekvencija}

Ispitivanje karakteristika distribucije frekvencija ostvarenih rezultata je potrebno radi odabira statističkih postupaka, jer ako neka distribucija značajno odstupa od normalne nije opravdana primjena parametrijskih statističkih postupaka.

Tabela 2: Pokazatelji za distribucije frekvencija

Legenda:

\begin{tabular}{lrrrr}
\hline Pokazatelj & URE & IIE & RUE & UEK \\
\hline $\mathrm{M}$ & 55,23 & 52,95 & 62,38 & 170,57 \\
$\mathrm{Med}$ & 55 & 53 & 62 & 169 \\
$\mathrm{Sk}$ & -.569 & -.073 & -.010 & .059 \\
$\mathrm{Ku}$ & 2,861 & .430 & -.110 & .324 \\
$\alpha$ & .841 & .815 & .869 & .867 \\
\hline
\end{tabular}

$\mathrm{M}=$ aritmetička sredina

Med $=$ medijan

$\mathrm{Sk}=$ skjunis

$\mathrm{Ku}=$ kurtozis

$\alpha=$ koeficijent pouzdanosti Crombach

$\mathrm{URE}=$ uočavanje i razumijevanje emocija

IIE = izražavanje i imenovanje emocija

RUE $=$ regulacija i upravljanje emocijama

$\mathrm{UEK}=$ ukupan skor na Upitniku 
Iz podataka prikazanih u Tabeli 2 uočava se da distribucije frekvencija ostvarenih rezultata po kriteriju simetričnosti i kurtičnosti, za subskale i Upitnik u cjelini, ne odstupaju značajno od normalne, te da se opravdano mogu koristiti parametrijski statistički postupci u obradi i analizi ostvarenih rezultata.

Dobijeni koeficijenti pouzdanosti (Tabela 2) imaju zadovoljavajuće vrijednosti za mjerne instrumente ove namjene i vrste.

\section{Uočavanje i razumijevanje emocija i statusna obilježja ispitanika (testiranje hipoteze $\mathrm{H}-1$ )}

Ukupan skor na subskali Uočavanja i razumijevanja emocija može se kretati u intervalu 15-75, a ostvarene aritmetičke sredine ispitanika jednog i drugog spola (Tabela 3) ukazuju na visok nivo ove dimenzije emocionalne kompetentnosti kod ispitanika.

Tabela 3: Uočavanje i razumijevanje emocija i spol ispitanika

Legenda:

\begin{tabular}{lrrrrr}
\hline Spol & $\mathrm{M}$ & $\mathrm{SD}$ & $\mathrm{MD}$ & $\mathrm{t}$ & $\mathrm{p}$ \\
\hline $\mathrm{M}$ & 54,00 & 6,17 & \multirow{2}{*}{1,53} & 1,51 & \multirow{2}{*}{131} \\
$\check{Z}$ & 55,53 & 4,87 & & & \\
\hline
\end{tabular}

$\mathrm{M}=$ aritmetička sredina

$\mathrm{SD}=$ standardna devijacija

$\mathrm{MD}=$ razlika aritmetičkih sredina

$\mathrm{t}=$ omjer

$\mathrm{p}=$ nivo značajnosti

Ispitanici ženskog spola su u prosjeku pokazali viši nivo kompetentnosti na dimenziji uočavanja i razumijevanja emocija $u$ odnosu na ispitanike muškog spola (Tabela 3). Međutim, ova razlika se nije pokazala statistički značajnom $(\mathrm{t}=1,55 ; \mathrm{p}=, 131 ; \mathrm{p}>0,05)$

Tabela 4: Uočavanje i razumijevanje emocija i vrsta nastave

Legenda:

\begin{tabular}{lrrrrr}
\hline Nastava & M & SD & MD & t & p \\
\hline Razr. & 54,84 & 5,94 & \multirow{2}{*}{1,92} & 1,97 &, $049^{*}$ \\
Pred. & 56,76 & 5,84 & & & \\
\hline
\end{tabular}

$\mathrm{M}=$ aritmetička sredina

$\mathrm{SD}=$ standardna devijacija

$\mathrm{MD}=$ razlika aritmetičkih sredina

$\mathrm{t}=$ omjer

$\mathrm{p}=$ nivo značajnosti 
Nastavnici koji izvode predmetnu nastavu ostvarili su u prosjeku veću vrijednost ukupnog skora na subskali Uočavanja i razumijevanja emocija (Tabela 4). Ova razlika se pokazala statistički značajnom $(\mathrm{t}=$ 1,97; $\mathrm{p}=, 049 ; \mathrm{p}<0,05)$, na osnovu čega se može $i$ u populaciji koju predstvalja ovaj uzorak, sa 95\% sigurnosti tvrditi da će nastavnici predmetne nastave pokazivati u prosjeku viši nivo kompetentnosti na dimenziji uočavanja i razumijevanja emocija.

Tabela 5: Uočavanje i razumijevanje emocija i starosna dob ispitanika

\begin{tabular}{lrrrrr}
\hline Starosna dob & $\mathrm{N}$ & $\mathrm{M}$ & $\mathrm{SD}$ & $\mathrm{F}$ & $\mathrm{p}$ \\
\hline 25-34 god. & 42 & 56,36 & 5,85 & & \\
35-44 god. & 102 & 55,27 & 6,34 & 1,222 &, 297 \\
45 i više god. & 79 & 54,58 & 5,48 & & \\
\hline
\end{tabular}

Legenda:

$\mathrm{N}=$ broj ispitanika

$\mathrm{M}=$ aritmetička sredina

$\mathrm{SD}=$ standardna devijacija

$\mathrm{F}=$ omjer

$\mathrm{p}=$ nivo značajnosti

Rezultati istraživanja (Tabela 5) su pokazali da prosječan nivo emocionalne kompetentnosti na dimenziji uočavanja i razumijevanja emocija raste sa starosnom dobi. Primjenom postupka jednofaktorske analize varijanse (ANOVA) nijedna od razlika među grupama ispitanika po starosnoj dobi nije se pokazala statistički značajnom $(\mathrm{F}=$ $1,222 ; \mathrm{p}=, 297 ; \mathrm{p}>0,05)$

Tabela 6: Uočavanje i razumijevanje emocija i radni staž ispitanika

\begin{tabular}{lrrrrr}
\hline Radni staž & $\mathrm{N}$ & $\mathrm{M}$ & $\mathrm{SD}$ & $\mathrm{F}$ & $\mathrm{p}$ \\
\hline do 10 god. & 49 & 56,10 & 6,01 & & \\
11-19 god. & 87 & 55,67 & 5,49 & & \\
20-29 god. & 83 & 54,35 & 6,24 & 1,224 &, 302 \\
30 i više god. & 4 & 53,50 & 8,96 & & \\
\hline
\end{tabular}

Legenda:

$\mathrm{N}=$ broj ispitanika

$\mathrm{M}=$ aritmetička sredina

$\mathrm{SD}=$ standardna devijacija

$\mathrm{F}=$ omjer

$\mathrm{p}=$ nivo značajnosti

Uporedo s dužinom radnog staža (Tabela 6) opada prosječan nivo kompetentnosti na dimenziji uočavanja i razumijevanja emocija. 
Međutim, nijedna od razlika među grupama ispitanika nije se pokazala statistički značajnom $(\mathrm{F}=224 ; \mathrm{p}=, 302 ; \mathrm{p}>0,05)$.

Rezimirajući rezultate analize o uticaju statusnih obilježja ispitanika na emocioalnu kompetentnost na dimenziji uočavanja $i$ razumijevanja emocija, može se zaključiti da na ovu dimenziju značajno utiče jedino vrsta nastave koju izvode nastavnici i jedino je u tom slučaju potvrđena polazna radna hipoteza $H-1$.

\section{Izražavanje $i$ imenovanje emocija i statusna obilježja ispitanika (testiranje hipoteze $\mathrm{H}-2$ )}

Ukupan skor na subskali Izražavanja i imenovanja emocija može se kretati u intervalu 14-70, a ostvarene aritmetičke sredine ispitanika jednog i drugog spola (Tabela 7) ukazuju na visok nivo ove dimenzije emocionalne kompetentnosti kod ispitanika.

Tabela 7: Izražavanje i imenovanje emocija i spol ispitanika

\begin{tabular}{lrrrrr}
\hline Spol & $\mathrm{M}$ & $\mathrm{SD}$ & $\mathrm{MD}$ & $\mathrm{t}$ & $\mathrm{p}$ \\
\hline $\mathrm{M}$ & 52,40 & 5,27 & \multirow{2}{*}{0,68} & 0,78 & \multirow{2}{*}{437} \\
$\mathrm{Z}$ & 53,08 & 5,18 & & & \\
\hline
\end{tabular}

Legenda:

$\mathrm{M}=$ aritmetička sredina

$\mathrm{SD}=$ standardna devijacija

$\mathrm{MD}=$ razlika aritmetičkih sredina

$\mathrm{t}=\mathrm{t}-$ omjer

$\mathrm{p}=$ nivo značajnosti

Analiza ostvarenih rezultata (Tabela 7) pokazuje da spol ispitanika $u$ ovom istraživanju ne predstavlja značajan faktor razlika u prosječnom nivou emocionalne kompetentnosti $u$ dimenziji izražavanja i imenovanja emocija $(\mathrm{t}=0,78 ; \mathrm{p}=, 437 ; \mathrm{p}>0,05)$.

Tabela 8: Izražavanje i imenovanje emocija i vrsta nastave

\begin{tabular}{lrrrrr}
\hline Nastava & M & SD & MD & t & p \\
\hline Razr. & 52,94 & 5,22 & \multirow{2}{*}{0,04} & 0,04 & \multirow{2}{*}{, 968} \\
Pred. & 52,98 & 5,15 & & & \\
\hline
\end{tabular}

Legenda:

$\mathrm{M}=$ aritmetička sredina

$\mathrm{SD}=$ standardna devijacija

$\mathrm{MD}=$ razlika aritmetičkih sredina

$\mathrm{t}=\mathrm{t}-$ omjer

$\mathrm{p}=$ nivo značajnosti 
U dimenziji izražavanja i imenovanja emocija među nastavnicima razredne i predmetne nastave (Tabela 8) razlika aritmetičkih sredina ukupnog skora se nije pokazala statistički značajnom $(t=0,78 ; p=, 968$; $\mathrm{p}>0,05)$.

Tabela 9: Izražavanje i imenovanje emocija i starosna dob ispitanika

Legenda:

\begin{tabular}{lrrrrr}
\hline Starosna dob & N & M & SD & F & p \\
\hline $25-34$ god & 42 & 53,12 & 6,39 & & \\
$35-44$ god & 102 & 53,03 & 5,11 & 0,087 &, 917 \\
45 i više god & 79 & 52,76 & 4,62 & & \\
\hline
\end{tabular}

$\mathrm{N}=$ broj ispitanika

$\mathrm{M}=$ aritmetička sredina

$\mathrm{SD}=$ standardna devijacija

$\mathrm{F}=\mathrm{F}-$ omjer

$\mathrm{p}=$ nivo značajnosti

I na dimenziji izražavanja i imenovanja emocija, kao i na dimenziji uočavanja i razumijevanja emocija, prosječan nivo ukupnog skora kod ispitanika opada sa starosnom dobi (Tabela 9). Međutim, nijedna od ovih razlika među grupama ispitanika se nije pokazala statistički značajnom $(\mathrm{F}=0,087 ; \mathrm{p}=, 917 ; \mathrm{p}>0,05)$.

Tabela 10: Izražavanje i imenovanje emocija i radni staž ispitanika

\begin{tabular}{lrrrrr}
\hline Radni staž & $\mathrm{N}$ & $\mathrm{M}$ & $\mathrm{SD}$ & $\mathrm{F}$ & $\mathrm{p}$ \\
\hline do 10 god. & 49 & 52,57 & 6,58 & & \\
$11-19$ god. & 87 & 53,60 & 4,35 & & \\
$20-29$ god. & 83 & 52,64 & 4,93 & 1,068 &, 364 \\
30 i više god. & 4 & 50,00 & 8,28 & & \\
\hline
\end{tabular}

Legenda:

$\mathrm{N}=$ broj ispitanika

$\mathrm{M}=$ aritmetička sredina

$\mathrm{SD}=$ standardna devijacija

$\mathrm{F}=\mathrm{F}-$ omjer

$\mathrm{p}=$ nivo značajnosti

Najviši nivo prosječnog skora na subskali Izražavanja i imenovanja emocija ostvarili su ispitanici s radnim stažom 11-19 godina (Tabela 10). Međutim, analiza je pokazala da nijedna od ovih razlika među grupama ispitanika nije statistički značajna $(\mathrm{F}=1,068 ; \mathrm{p}=, 364 ; \mathrm{p}>$ $0,05)$. 
Tabela 11: Izražavanje i imenovanje emocija u odnosu na razliku starosti $i$ staža ispitanika

\begin{tabular}{llllll}
\hline $\begin{array}{l}\text { Razlika } \\
\text { (starost - staž) }\end{array}$ & $\mathrm{N}$ & $\mathrm{M}$ & $\mathrm{SD}$ & $\mathrm{F}$ & $\mathrm{p}$ \\
\hline 19-24 god. & 110 & 52,40 & 5,30 & &, 049 \\
25-34 god. & 104 & 53,75 & 5,04 & 2,947 & $*$ \\
35 i više god & 9 & 50,44 & 4,33 & & \\
\hline
\end{tabular}

Legenda:

$\mathrm{N}=$ broj ispitanika

$\mathrm{M}=$ aritmetička sredina

$\mathrm{SD}=$ standardna devijacija

$\mathrm{F} \quad=\mathrm{F}-$ omjer

$\mathrm{p}=$ nivo značajnosti

Iako se razlike u prosječnom nivou na dimenziji izražavanja i imenovanja emocija nisu pokazale statistički značajnim među grupama ispitanika s obzirom na starosnu dob, niti s obzirom na dužinu radnog staža, potvrđen je statistički značajan zajednički uticaj ovih prediktora (Tabela 11). Razlika starosne dobi i dužine radnog staža pokazuje u kojoj starosnoj dobi je osoba počela sa svojom nastavničkom profesijom.

Po ovom osnovu zajedničkog djelovanja starosti i staža utvrđeno je postojanje statistički značajne razlike $u$ aritmetičkim sredinama skora na subskali Izražavanja i imenovanja emocija $(F=2,947 ; p=, 049 ; p$ $<0,05)$, a Scheffe-test pokazuje značajnom ovu razliku $(p=, 043 ; p<$ 0,05) između ispitanika koji su počeli raditi u starosnoj dobi 25-34 godine $(M=53,75)$ i onih koji su počeli raditi sa 35 i više godina života $(M=50,44)$.

\section{Regulacija i upravljanje emocijama i statusna obilježja ispitanika (testiranje hipoteze $\mathrm{H}-3$ )}

Ukupan skor na subskali Regulacije i upravljanja emocijama može se kretati u intervalu 16-80, a ostvarene aritmetičke sredine ispitanika jednog i drugog spola (Tabela 12) ukazuju na visok nivo ove dimenzije emocionalne kompetentnosti kod ispitanika. 
Tabela 12: Regulacija i upravljanje emocijama i spol ispitanika

Legenda:

\begin{tabular}{llllll}
\hline Spol & $\mathrm{M}$ & $\mathrm{SD}$ & $\mathrm{MD}$ & $\mathrm{t}$ & $\mathrm{p}$ \\
\hline $\mathrm{M}$ & 62,65 & 5,25 & \multirow{2}{*}{0,33} & \multirow{2}{*}{0,37} & \multirow{2}{*}{708} \\
$\check{Z}$ & 62,32 & 5,24 & & & \\
\hline
\end{tabular}

$\mathrm{M}=$ aritmetička sredina

$\mathrm{SD}=$ standardna devijacija

$\mathrm{MD}=$ razlika aritmetičkih sredina

$\mathrm{t}=\mathrm{t}$-omjer

$\mathrm{p}=$ nivo značajnosti

Ispitanici muškog spola su ostvarili nešto veću prosječnu vrijednost ukupnog skora na subskali Regulacije i upravljanja emocijama (Tabela 12). Međutim, ova se razlika nije pokazala statistički značajnom ( $\mathrm{t}=$ $0,37 ; \mathrm{p}=, 708 ; \mathrm{p}>0,05)$

Tabela 13: Regulacija i upravljanje emocijama $i$ vrsta nastave

Legenda:

\begin{tabular}{lrrrrr}
\hline Nastava & M & SD & MD & t & p \\
\hline Razr. & 62,07 & 5,11 & \multirow{2}{*}{1,52} & 1,76 &, 080 \\
Pred. & 63,59 & 5,61 & & & \\
\hline
\end{tabular}

$\mathrm{M}=$ aritmetička sredina

$\mathrm{SD}=$ standardna devijacija

$\mathrm{MD}=$ razlika aritmetičkih sredina

$\mathrm{t}=\mathrm{t}-$ omjer

$\mathrm{p}=$ nivo značajnosti

Nastavnici predmetne nastave su ostvarili veći prosječan nivo na dimenziji regulacije i upravljanja emocjama u odnosu na nastavnike razredne nastave (Tabela 13). Međutim, ova se razlika nije pokazala statistički značajnom $(\mathrm{t}=1,76 ; \mathrm{p}=, 080 ; \mathrm{p}>0,05)$

Tabela 14: Regulacija i upravljanje emocijama i starosna dob ispitanika

\begin{tabular}{lrrrrr}
\hline Starosna dob & $\mathrm{N}$ & $\mathrm{M}$ & $\mathrm{SD}$ & $\mathrm{F}$ & $\mathrm{p}$ \\
\hline 25-34 god. & 42 & 63,83 & 5,17 & & \\
35-44 god. & 102 & 62,44 & 5,39 & 2,699 &, $047^{*}$ \\
45 i više god. & 79 & 61,53 & 4,96 & & \\
\hline
\end{tabular}

Legenda:

$\mathrm{N}=$ broj ispitanika

$\mathrm{M}=$ aritmetička sredina

$\mathrm{SD}=$ standardna devijacija

$\mathrm{F} \quad=\mathrm{F}-$ omjer

$\mathrm{p}=$ nivo značajnosti 
Rezultati istraživanja (Tabela 14) su pokazali da starosna dob nastavnika značajno utiče na dimenziju regulacije $i$ upravljanja emocijama $(F=2,699 ; p=, 047 ; p<0,05)$. Primjenom Scheffe-testa potvrđena je značajna razlika po ovom osnovu između ispitanika starosne dobi 25-34 godine i onih sa starosnom dobi od 45 i više godina $(p=0,044 ; p<0,05)$.

Tabela 15: Regulacija i upravljanje emocijama i radni staž ispitanika

\begin{tabular}{lrrrrr}
\hline Radni staž & N & M & SD & F & p \\
\hline do 10 god. & 49 & 62,92 & 5,70 & & \\
11-19 god. & 87 & 62,93 & 5,15 & 1,395 &, 245 \\
20-29 god. & 83 & 61,63 & 4,88 & & \\
30 i više god. & 4 & 59,75 & 7,84 & & \\
\hline
\end{tabular}

Legenda:

$\mathrm{N}=$ broj ispitanika

$\mathrm{M}=$ aritmetička sredina

$\mathrm{SD}=$ standardna devijacija

$\mathrm{F} \quad=\mathrm{F}-$ omjer

$\mathrm{p}=$ nivo značajnosti

Među grupama ispitanika s obzirom na radni staž (Tabela 15) nijedna od razlika u aritmetičkim sredinama ukupnog skora na subskali Regulacije i upravljanja emocijama se nije pokazala statistički značajnom $(\mathrm{F}=1,395 ; \mathrm{p}=, 245 ; \mathrm{p}>0,05)$.

Rezimirajući rezultate analize o uticaju statusnih obilježja ispitanika na regulaciju $i$ upravljanje emocijama, polazna radna hipoteza $\mathrm{H}-3$ dokazana je jedino u slučaju uticaja starosne dobi ispitanika.

\section{Ukupna emocionalna kompetentnost i statusna obilježja ispitanika (testiranje hipoteze $\mathrm{H}-4$ )}

Ukupan skor na Upitniku emocionalne kompetentnosti može se kretati u intervalu 45-225, a ostvarene aritmetičke sredine ispitanika u svakoj od grupa po izdvojenim statusnim obilježjima i za uzorak u cjelini , ukazuju na visok nivo ukupne emocionalne kompetentnosti kod ispitanika. 
Tabela 16: Ukupna emocionalna kompetentnost i spol ispitanika

Legenda:

\begin{tabular}{lrrrrr}
\hline Spol & M & SD & MD & t & p \\
\hline$M$ & 169,05 & 13,05 & \multirow{2}{*}{1,88} & 0,85 & \multirow{2}{*}{395} \\
$\check{Z}$ & 170,93 & 12,99 & & & \\
\hline
\end{tabular}

$\mathrm{M}=$ aritmetička sredina

$\mathrm{SD}=$ standardna devijacija

$\mathrm{MD}=$ razlika aritmetičkih sredina

$\mathrm{t}=\mathrm{t}$-omjer

$\mathrm{p}=$ nivo značajnosti

Razlike u prosječnom nivou ukupne emocionalne kompetentnosti među ispitanicima s obzirom na spol (Tabela 16) nisu se pokazale statistički značajnim $(\mathrm{t}=0,85 ; \mathrm{p}=, 395 ; \mathrm{p}>0,05)$.

Tabela 17: Ukupna emocionalna kompetentnost $i$ vrsta nastave

Legenda:

\begin{tabular}{lrrrrr}
\hline Nastava & $\mathrm{M}$ & $\mathrm{SD}$ & $\mathrm{MD}$ & $\mathrm{t}$ & $\mathrm{p}$ \\
\hline Razr. & 169,85 & 12,82 & \multirow{2}{*}{3,48} & 1,62 &, 106 \\
Pred. & 173,33 & 13,41 & & & \\
\hline
\end{tabular}

$\mathrm{M}=$ aritmetička sredina

$\mathrm{SD}=$ standardna devijacija

$\mathrm{MD}=$ razlika aritmetičkih sredina

$\mathrm{t}=\mathrm{t}$-omjer

$\mathrm{p}=$ nivo značajnosti

Iako se vrsta nastave pokazala značajnim prediktorom razlika $\mathrm{u}$ prosječnom nivou dimenzije uočavanja i razumijevanja emocija, razlika $\mathrm{u}$ ukupnom nivou emocionalne kompetentnosti po ovom osnovu (Tabela 17) nije potvrđena statistički značajnom $(\mathrm{t}=1,62 ; \mathrm{p}=106 ; \mathrm{p}$ $>0,05)$.

Tabela 18: Ukupna emocionalna kompetentnost $i$ starosna dob ispitanika
$\mathrm{N}=$ broj ispitanika
$\mathrm{M}=$ aritmetička sredina
$\mathrm{SD}=$ standardna devijacija
$\mathrm{F}=\mathrm{F}$-omjer
$\mathrm{p}=$ nivo značajnosti 
Prosječan nivo ukupne emocionalne kompetentnosti opada sa starosnom dobi (Tabela 18). Međutim, nijedna od razlika među grupama po ovom obilježju nije se pokazala statistički značajnom ( $\mathrm{F}=$ $1,626 ; \mathrm{p}=, 199 ; \mathrm{p}>0,05)$.

Iako su među grupama ispitanika s obzirom na radni staž utvrđene razlike u ukupnom nivou emocionalne kompetentnosti (Tabela 19), nijedna od ovih razlika se nije pokazala statistički značajnom ( $\mathrm{F}=$ 1,$612 ; \mathrm{p}=, 188 ; \mathrm{p}>0,05$.)

Tabela 19: Ukupna emocionalna kompetentnost i radni staž ispitanika

Legenda:

\begin{tabular}{lrrrrr}
\hline Radni staž & $\mathrm{N}$ & $\mathrm{M}$ & $\mathrm{SD}$ & $\mathrm{F}$ & $\mathrm{p}$ \\
\hline do 10 god. & 49 & 171,59 & 14,25 & & \\
$11-19$ god. & 87 & 172,18 & 12,22 & & \\
$20-29$ god. & 83 & 168,61 & 12,35 & 1,612 &, 188 \\
30 i više god. & 4 & 163,25 & 22,69 & & \\
\hline
\end{tabular}

$\mathrm{N}=$ broj ispitanika

$\mathrm{M}=$ aritmetička sredina

$\mathrm{SD}=$ standardna devijacija

$\mathrm{F} \quad=\mathrm{F}-$ omjer

$\mathrm{p}=$ nivo značajnosti

Rezimirajući analizu ostvarenih ukupnih rezultata na Upitniku emocionalne kompetentnosti, polazna radna hipoteza $\mathrm{H}-4$ nije potvrđena ni po jednom od kriterija, odnosno, ukupna emocionalna kompetentnost nije značajno uvjetovana spolom, vrstom nastave, starosnom dobi, niti dužinom radnog staža nastavnika.

\section{ZAKLJUČAK}

Rezimirajući rezultate analize o uticaju statusnih obilježja ispitanika na dimenziji uočavanja i razumijevanja emocija može se zaključiti da na ovu dimenziju značajno utiče jedino vrsta nastave koju izvode nastavnici.

Po osnovu zajedničkog djelovanja starosti i staža utvrđeno je postojanje statistički značajne razlike $\mathrm{u}$ aritmetičkim sredinama skora na subskali Izražavanja i imenovanja emocija: ispitanici koji su počeli raditi $\mathrm{u}$ starosnoj dobi 25-34 godine pokazali su u prosjeku viši nivo na ovoj subskali u odnosu na one koji su počeli raditi sa 35 i više godina života. 
Rezultati istraživanja su pokazali da starosna dob nastavnika značajno utiče na dimenziju regulacije i upravljanja emocijama: ispitanici starosne dobi 25-34 godine pokazali su u prosjeku viši nivo na ovoj dimenziji kompetentnosti u odnosu na ispitanike starosne dobi od $45 \mathrm{i}$ više godina.

Analiza ostvarenih rezultata je potvrdila da ukupna emocionalna kompetentnost nije značajno uvjetovana spolom, vrstom nastave, starosnom dobi, niti dužinom radnog staža nastavnika.

\section{Literatura:}

1. Bratanić, M. (1993) Mikropedagogija, interakcijsko-komunikacijski aspekt odgoja, Zagreb: Školska knjiga.

2. Davies, M., Bryer, F. (2004) Personal Skills for Teachers: Measuring and Developing Their Emotional Competencies, Griffith University, I: 246-258.

3. Goleman, D. (1998) Working with emotional inteligence, New York: Bantam Books.

4. Goleman, D. (2007) Socijalna inteligencija: nova nauka o ljudskim odnosima, Beograd: Geopoetika.

5. Goleman, D. (2009) Emocionalna inteligencija, Beograd: Geopoetika.

6. Kaplan, R. E. (1991) Beyond ambition: How driven managers can lead Better and live better, San Francisco: Jossey Bass.

7. Milivojević, Z. (2000) Emocije-psihoterapija i razumijevanje emocija, Novi Sad: Prometej.

8. Reić - Ercegovac, I. Koludrović, M. Jukić, T. (2009) Emocionalna kompetentnost i stres u nastavničkim zanimanjima, Split: Filozofski fakultet Sveučilišta u Splitu.

9. Suzić, N. (2005): Pedagogija za XXI vijek, Banjaluka: TT - Centar.

10. Takšić, V. (2002) Upitnici emocionalne inteligencije (kompetentnosti), U: Lacković - Grgin, K., Bautović, A. Ćubela, V. i Penezić, Z. (ur.) : Zbirka psihologijskih skala i upitnika, Zadar: Filozofski fakultet u Zadru, str. 27-45. 


\title{
EMOTIONAL COMPETENCE IN TEACHING PROFESSION
}

\author{
PhD Fehim Rosicic, Islamic Faculty of Pedagogy \\ University of Bihać \\ E-mail:fehim.rosic@gmail.com
}

Abstract:

The problem of this research involves the emotional competence of teachers, and the aim of the research is to examine the importance and magnitude of the influence of gender, type of teaching, age and length of teachers' work experience on the level of their emotional competence. The research was conducted by the UEK-45 Questionnaire on a sample of 225 primary and secondary school teachers from the Una-Sana Canton, and according to the draft it is a comparative research of a retrospective and prospective type. The results of the research showed that there are differences in arithmetic means of the total score and results on the subscales of the UEK-45 Questionnaire with respect to the criteria variables of gender, types of teaching, age and length of service of teachers, and by testing the significance of these differences by t-test and Analysis of variance (ANOVA) the significance of the differences was confirmed: with regard to the type of teaching on the Emotion Observation and Understanding (EEU) subscale, with respect to age on the Regulation and Management of Emotions (ERO) subscale among subjects aged 25-34 and those with 45 and years, and on the Emotions and Naming Emotions (IIE) subscale, considering the difference in age and length of service between teachers with this difference in the 25-34 age range and those with this difference of 45 years or more.

Keywords: emotional competence, perception and understanding of emotions, naming and expression of emotions, regulation and management of emotions, empathy. 


\section{الأستاذ الدكتور فهيم روشيتش$$
\text { جامعة بيهاتش }
$$$$
\text { كلية التربية الإسلامية }
$$ \\ E-mail:fehim.rosic@gmail.com \\ الكفاءة العاطفية في مهنة التدريس}

\section{الملخص}

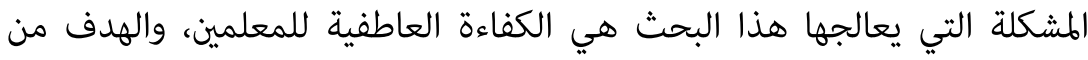

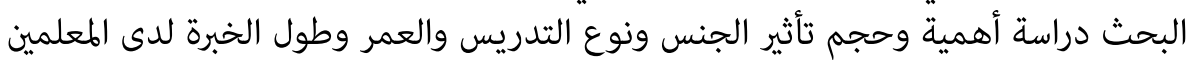

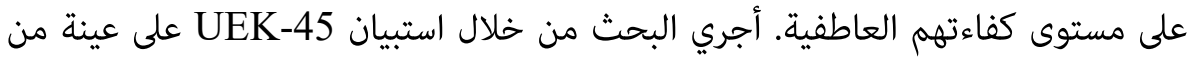

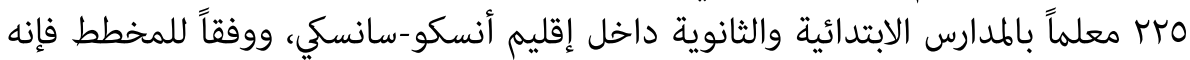

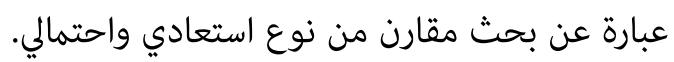

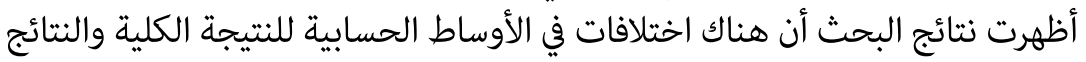

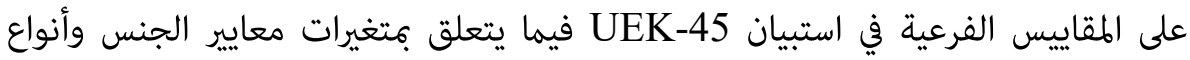
التدريس والعمر وطول الخدمة. وباختبار أهمية هذه الاختلافات عن طريق اختبار t وتحليل التباين (ANOVA) ) تم التأكيد على أهمية الاختلافات:

- فيما يتعلق بنوع التدريس في مقياس فرعي لمراقبة العاطفة والتفاهم (URE)،

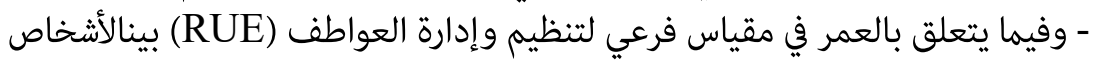

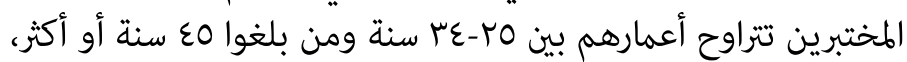

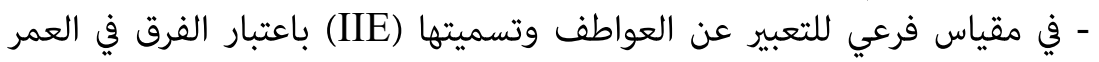

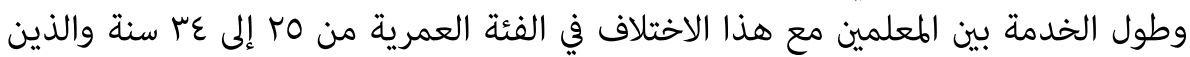

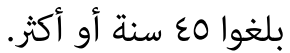

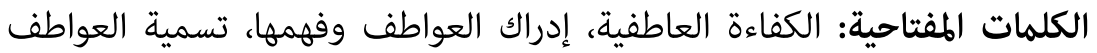

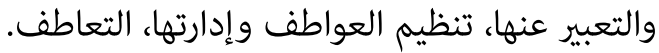

